\title{
PELAKSANAAN PENGADAAN TANAH BAGI PEMBANGUNAN UNTUK KEPENTINGAN UMUM (STUDI DI KOTA MAKASSAR)
}

\author{
Sulastri M, Syamsuddin Pasamai, H.M.Kamal Hidjaz \\ Program Pascasarjana Universitas Muslim Indonesia
}

\begin{abstract}
The focus of the research is based on facts in the field regarding public land acquisition. Besides wanting to know how the land acquisition process is, it also wants to know the factors that influence land acquisition for the public interest in the city of Makassar. This research is legal research (empirical research) with a legal approach (statute approach). The results of the study indicate that the politics of land law in Indonesia is contained in the LoGA, that the state is not the owner so that the state does not own land. Therefore, the UUPA is not known as eigendom. However, the existence of a state within the scope of the land is only authorized to regulate various issues relating to land in Indonesia, including the authority of land regulation that is increasingly important especially if there are government agencies that need land as the land where development is carried out in the public interest. land to government agencies for development in the public interest, it is deemed necessary to have a legal rule that can be used as a reference in a positive law.
\end{abstract}

Keywords: Land, Land Procurement, General Interest

Abstrak: Fokus penelitian didasarkan pada fakta-fakta yang ada di lapangan terkait pengadaan tanah kepentingan umum. Di samping ingin mengetahui bagaimana proses pengadaan tanah, juga ingin mengetahui faktor-faktor yang mempengaruhi pengadaan tanah untuk kepentingan umum di kota Makassar.Penelitian ini adalah penelitian hukumemperis (empirical research) dengan pendekatan hukum (statute approach). Hasil penelitian menunjukkan bahwa politik hukum pertanahan di Indonesia termuat di dalam UUPA, bahwa negara bukan pemilik sehingga negara tidak memiliki tanah. Oleh karena itu, di dalam UUPA tidak dikenal istilah eigendom. Akan tetapi keberadaan negara dalam lingkup pertanahan, hanya diberi wewenang mengatur terhadap berbagai persoalan yang menyangkut pertanahan di Indonesia, termasuk wewenang pengaturan pertanahan yang semakin penting terutama apabila ada instansi pemerintahanyang membutuhkan tanah sebagai lahan tempat pelaksanaan pembangunan untuk kepentingan umum.Tercapainya kepastian hukum dalam pemenuhan kebutuhan tanah terhadap instansi pemerintah bagi pembangunan untuk kepentingan umum, dipandang perlu adanya suatu aturan hukum yang dapat dijadikan acuan secara hukum positif.

Kata Kunci: Pertanahan, Pengadaan Tanah, KepentinganUmum 


\section{LATAR BELAKANG}

Pada prinsipnya, pembangunan merupakan salah satu kewajibannegara melalui pemerintah dalam berupaya mewujudkan masyarakat yang adil, makmur dan sejahtera berdasarkan nilainilai luhur yang tersebar di dalam kelima sila dari Pancasila. Tugas pembangunan dimaksud, jugadiamankan di dalam Undang-Undang Dasar Negara Republik Indonesia (UUD) Tahun 1945sebagai constitusional right.

Salah satu bentuk pembangunan yang diselenggarakan negara (pemerintah) erat kaitannya dengan peningkatan kesejahteraan rakyat atau masyarakan, yakni pembangunan untuk kepentingan umum. Sedang pembangunan untuk kepentingan umum, secara faktual memerlukan tanah yang pemgadaannya dilaksanakan dengan berupaya semaksimal mungkin lebih mengedepankan prinsipprinsip dasar yang terkandung di dalam rumusan Pasal 33 atau (3) UUD Tahun 1945 dan hukum tanah.

Pasal 33 ayat (3) UUD Tahun 1945, berbunyi Bumi dan air dan kekayaan alam yang terkandung di dalamnya dikuasai oleh negara dan dipergunakan untuk seesarbesarnya kemakmuran rakyat. Landasan konstitusional inilah yang menjadi jiwa dan semangat Hukum TanahNasional.
Undang-undang Nomor 5 Tahun 1960 tentang Peratiran dasar Pokok-pokok Agraria, ataulebih dikenal dengan Undangundang Pokok Agraria disingkat UUPA, serta merupakan bagian integral dan tidak terpisahkan dari Hukum Agraria Indonesia.

Kemudian di dalam rumusan Pasal 2 ayat (2) UUPA, secara tegas dan transparan telah memberikan wewenang pengaturan kepada negara di bidang pertanahan. Kewenangan negara atas tanah dimaksud, semata- mata untuk :

a. Mengatur dan menyelenggarakan peruntukan, penggunaan, persediaan dan pemeliharaan bumi, air dan ruang angkasa;

b. Menentukan dan mengatur hubungan-hubungan hukum antara orang-orang dngan bumi, air dan ruang angkasa;

c. Menentukan dan mengatur hubungan-hubungan hukum antaraorang-orang dan perbuatan=perbuatan hukum yangmengenai bumi, air dan ruang angkasa.

Sehubungan dengan hal tersebut, maka hak menguasai tanah dari negara berarti negara (pemerintah) bukan pemilik tanah, akan tetapi pemerintah berhak mengatur peruntukan, pengunaan, persediaan dan pemeliharaan tanah. 
Sekaligus mengatur hubungan hukum antara orang dengan tanah, serta mengatur perbuatan-perbuatan hukum terhadap tanahdengan tetap memperhatikan fungsi sosial hak atas tanah sebagaimana dimaksud Pasal 6 UUPA.

Pelaksanaan program pembangunan yang dilakukan oleh instansi pemerintah, secara ex officio memerlukan lahan atau tanah sebagai lokasi tempat merealisasikan fisik guna membanguan sarana dan prasarana kepentingan umum. Sedang makna dari kepentingan umum disini, tidak menjadikan rakyat sengsara tetapi bertujuan untuk meningkatkan kemakmuran dan kesejahteraan rakyat, khususnya pemilik tanah.

Berkenan dengan hal tersebut, sehingga pembangunan fisik yang dilakukan ileh instansi pemerintah senantiasa membutuhkan lahan atau tanah guna dijadikan sebagai lokasi dan/atau tempat mendirikan jenis bangunan.Namun ada issu sentral yang berkembang di tengah-tengahmasyrakat, bahwa kebutuhan tanah semakin meningkat sementyara luas tanah tidak bertambah. Sekiranya dpertautkan dengan persoalan vertilitas penduduk yang semakin meningkat, tentu setiap orang membutuhkan tuntutan hidup keluarga dan rumah tangga.
Isu negatif yang demikian, berpotensi mempengaruhi masyarakat pemilik atau pemegang hak atas tanah untuk tidak melepaskan bidang-bidang tanahnya kepada instansi pemerintah yang membutuhkan tanah. Kalau pemilik atau pemegang hak atas tanah ternyata bersedia melepaskan tanahnya, tentu dengan harga ganti kerugian yang relatif cukup mahal agar agar tidak jadi diambil atau dibayar oleh instansi yang membutuhkan tanah. Bahkan kedudukan tanah menjadi semakin strategis, karena tanah dibutuhkan untuk hidup dan matinya sekalipun.

Hal yang demikian itu, perlu adanya kebijakan pemerintah mengatur berbagai aspek berkenaan dengan tanah bagi pembangunan untuk kepentingan umum. Sedang kebijakan pemerintah dalam rangka pengadaan tanah tesebut, idealnya bilamana dituangkan dalam bentuk peraturan perundang-undangan, sehingga cukup tersedia bidang tanah yang dibutuhkan dalam rangka pembangunan untuk kepentingan umum.

Persoalan pengadaan tanah bagi pelaksanaan pembangunan untuk kepentimngan umum, dewasa ini telah ada regulasi yang diatur secara limitatif dalam UU. Nomor 2 Tahun 2012 tentang \{engadaan Tanah bagi Pembangunan Untuk Kepentingan Umum ( Lembaran Negara Republik Indonesia Tahun 2012 
nomor 22, Tambahan Lembaran Negara Republik Indonesia 5280), berikut berbagai peraturan pelaksanaannya.

Walaupun telah ada berbagai regulasi yang mengatur pelaksanaan pengadaan tanah utnuk kepentingan umum, namun pelaksanaannya masih sering diperhadapkan dengan berbagai persoalan hukum. Oleh karena itu, maka terhadap persoalan-persoalan hukum yang timbul dalam pelaksanaan pengadaan tanah menjadi hambatan dan kendala, Apabila hambatan dan kembdala sudah terdeteksi, harus segera di ganti guna ditemukan solusi pemecahan masalahnya sehingga tidak mengorbankan masyarakat pemilik atau pemegang hak atas tanah.

Untuk merujuk alasan-alasan filosofis, dan sosio-judis terhadap pelaksanaan pengadaan tanah bagi pembangunan untuk kepentingan umum tersebut, memberikan motovasi untuk melakukan penelitian ilmiah. Hasil penelitian akan dituangkan dalam tesis yang berjudul; Pelaksanaan Pengadaan Tanah bagi Pembangunan Untuk Kepentingan Umum.

\section{METODE PENELITIAN}

Penelitian ini adalah penelitian hukum emperis (empirical research) dengan pendekatan hukum (statute
approach).Fokus penelitian didasarkan pada fakta-fakta yang ada di lapangan terkait pengadaan tanah kepentingan umum. Di samping ingin mengetahui bagaimana proses pengadaan tanah, juga ingin mengetahui faktor-faktor yang mempengaruhi pengadaan tanah untuk kepentingan umum di kota Makassar.

Penelitian akan berlangsung dalam wilayah Kota Makassar, karena daerah ini sedang giat-giatnya melaksanakan pembangunan di semua lini kehidupan masyarakat. Salah satu jenis program pembangunan yang akan dilaksanakan di Kota Makassar adalah membuat jalan atau pelebaran jalan. Penyelenggaraan program pembuatan pelebaran jalan, tentu memerlukan tanah atau lahan tempat pelaksanaan pembangunan.

\section{LANDASAN TEORETIS}

Secara konseptual, penegakkan hukum senantiasa terkait dengan masalah kesadaran, ketaatan dan kepatuhan hukum yang berorientasi pada penegakan hukum (law envorment). Sementara penegakkan hukum adalah penting karena Indonesia adalah negara hukum. Hal ini termuat dengan jelas dalam rumusan UUD 1945 pada pasal 1 ayat (3) bahwa negara Republik Indonesia adalah negara hukum. 
Penegakan hukm adalah merupakan prasyarat suatu negara hukum dan sekaligus sebagai upaya mengaplikasikan hukum. Maksudnya agar melalui upaya penegakan hukum diharapkan dapat terlaksana sesuai dengan tujuan hukum dalam masyarakat. Soerjono Sekanto mengemukakan bahwa ada lima faktor yang mempengaruhi penegakan hukum sebagai berikut:

a. Faktor hukumnya sendiri yaitu peraturan perundang-undangan yang diberlakukan;

b. Faktor penegakan hukum yaitu pihak-pihak yang membentuk maupun pemerapan hukum

c. Faktor sarana atau fasilitas yang mendukung penegak hukum

d. Faktor masyarakat yaitu lingkungan dimana hukum itu diberlakukan atau diterapkan

e. Faktor kebudayaan yaitu sebagai hasil karya, cipta dan rasa yang didasarkan pada karsa manusia di dalam pergaulan hidup.

Kelima faktor tersebut saling berkaitan dengan eratnya, oleh karena merupakan esensi dari penegakkan hukum juga merupakan tolak ukur dari pada efeltivitas penegakan hukum. Satjipto
Rahardjo mengemukakan bahwa $^{1}$ "Penegakan Hukum adalah suatu proses untuk mewujudkan keuinginan hukum menjadi kenyataan”. Dimaksud dengan keinginan hukum adalah pfikiran-fikiran badan pembuat undang-undang yang dirumuskan dalam peraturan-peraturan hukum, segingga proses penegakan hukum menjangkau pula sampai pembuatan hukum.

Apabila dikaitkan dengan penegakan hukum dalam sistem peradilan pidana maka berarti menunjuk bagaimana efektivitas penegak hukum dalam sistim peradilan pidana dapat diwujutkan sesuai dengan keinginan pembentuk undangundang dalam masyarakat.Penggunaan konsep efektivitas adalah menggunakan secara umum untuk menggambarkan pencapaian tujuan sesuai dengan rencana. Menurut Poerwadarminta menyatakan bahwa : efektiviatas adalah seuatu keadaan yang mengandung pengertian mengenai suatu terlaksananya suatu apa yang dikehendaki”. Kalau seseorang melakukan suatu perbuatan dengan maksud sebagaimana yang dikehendaki maka efektivitas kerja manusia adalah keadaan atau kemampuan berhasilnya suatu

${ }^{1}$ Satjipto Rahardjo, llmuHukum.

(Bandung: Alumni. 1986) . Hlm 24 
pekerjaan yang dilakukan diharapkan dapat tercapai.Dengandemikian, apabila suatu tujuan telah tercapai dengan baik maka hal itu dapat disebut efektif, sehingga dalam suatu organisasi bila ia dapat melaksanakan tugas pokoknya dengan dasar peraturan perundang-undangan maka itupun dapat dikatakan terlaksana.

Menurut Ahmad Ali, mengemukakan bahwa "Kapan suatu undang-undang dianggap tidak berlaku?" Jawabnya tentu saja jika sebahagian besar warga masyarakattidak mentaatinya. Namun demikian, jika sebahagian besar masyarakat yang karena ketaatan hukum bahkan mentaatinya aturan dalam undangundang tersebut, maka aturan atau kualitas efektivitas aturan undang-undang itupun masih dapat dipertanyakan mengapa demikian?

Hal itu disebabkan karena ketaatan hukum itu sendiri masih dapat dibedakan kualitasnya dalam tiga jenis seperti yang dikemukakan H.C.Kelman yakni ${ }^{3}$ :

a. Ketaatan yang bersifat complience yaitu jika seseorang taat terhadap sesuatu aturan hanya karena takut kena sanksi,

\footnotetext{
${ }^{2}$ Achmad Ali, Mempelajari Kajian Empiris

Terhadap Hukum. Jakarta,
}

Watampone.1998). Hlm.1993

${ }^{3}$ ibid b. Ketaatan yang bersifat identifiationyaitu jika seseorang taat terhadap suatu aturan hanya kerena takut hubungan baiknya dengan seseorang menjadi rusak,

c. Ketaatan yang bersifat internalization yaitu jika seseorang taat kepada suatu aturan karena benar-benar ia merasa aturan itu sesuai dengan nilali-nilai interfensik yang dianutnya.

Menyikapi teori penegakkan hukum tersebut di atas maka ukuran berlaku efektif tidaknya suatu undang-undang atau perundang-undangan tergantung dari seberapa jumlah masing-masing (badan/instansi) maupun orang perorang yang mengikutinya. Akan tetapi itupun harus dapat diukur tingkat kualitasnya dan ktaatannya dalam melaksanakan suatu unang undang atau peraturan mana dari ketiga pendapat Kalman tersebut yang dipakai maka dianjurkan sebaliknya dan idealnya ketaatan interlization yang dianut atau dianggap yang baik.

Penggunaan hukum sebagai alat menekat masyarakat oleh pemerintah totaliter seperti ini misalnya dalam bentuk dalam mengirin opesisi atau musuh penguasa ke dalam penjara atau ketiang gantungan yang menurut Syahran Basah bahwa fungsi hukum dapat dibedakan menjadi dua bagian yaitu : fungsi internal dan fungsi eksternal/ fungsi internal adalah fungsi sebagai pertauran perundang- 
undangan sedangkan fungsi eksternal adalah berfungsi sebagai sub-sistem hukum terhadap sistem hukum pada umumnya jastifikasi secara semu oleh pengadilan.

\section{PEMBAHASAN}

1. KONSEP PENGADAAN TANAH BAGI PEMBANGUNAN

Istilah pengadaan tanah sering diidentikkan dengan kebutuhan tanah, kalau pengadaan tanah sifatnya aktif dan bagi penyediaan tanah sifatnya pasif. Bahkan istilah pengadaan tanah, sering pula dipersamakan dengan penyediaan tanah Istilah penyediaan tanah pertama kali termuat dalam Peraturan Manteri Dalam Negeri (Permendagri) nomor 15 Tahun 1975, yentang ketentuan-jetentuan Mengenai Tata Cara Pembebasan Tanah, sementara istilah pengadaan tanah untuk pertama kali termuat dalam Permendagri nomor 2 Tahun 1985 tentang Tata Cara Pengadaan Tanah untuk keperluannProyek Pembangunan di Wilayah kecamatan.

Pengadaan tanah dimaksud, tidak berorientasi kepada pengertian hukum tanahyang di dalamnya hanya terkandung satu dimensi yakni dimensi hak ats tanah saja. Akan tetapi berorientasi kepada pengertian agraria yang di dalamnya terkandung tiga dimensi, yakni dimensi tanah, dimensi terhadap segala yang ada di atas tanah, serta dimensi terhadap segala apa yang ada dan terkandung di bawah tanah, namun istilah pengadaan tanah tersebut, pelaksanaannya dpat dipaksakan melalui pemcabutan hak atas tanah menurut UU Nomor 20 Tahun 1961.

Kemudian dalam Pepres nomor 65 Tahun 2006 tentang Perubahan atas Perpres nomor 36 Tahun 2005 enyang pengadaan tanah bagi pelaksanaan pembanguan untuk kepentingan umum. Pasal 1 angka 3 bahwa Pengadaan tanah adalah setiap kegiatan untuk mendapatkan tanah dengan memberikan ganti rugi kepada yang melepaskan atau menyerahkan tanah, banguan, tanaman dan benda-benda yang terlait dengan tanah. Isini telah dikeluarkan lembaga pemcabutan hakatas tanah dari pengertia pangadaan tanah.

Dalam UU Nomor 2 Tahun 2012 tentang Pengadaan/ tanah Bagi Pembanguan untuk Kepentingan Umum, pada pasal 1 angka 2 ditegaskan bahwa: Pengadaan tanah adalah kegiatan menyediakan tanah denga cara memberi ganti kerugian yang layak dan adil kkepada pihak yang menguasai atau memiliki obyek pengadaan tanah. UU Nomor 2 Tahun 2012 juga tidak mengenal upaya pencabutan hak atas tanah sebagai bagian dari pengadaan tanah. 
Menurut rumusan pasal 1 angka 4 UU Nomor 2 Tahun 2012 dimaksud obyek pengadaan tanah adalah tanah, ruang atas tanah dan bawah tanah, bangunan, tanaman, benda yang berkaitan dengan tanah atau lainnya yang dapat dinilai. Oleh karena itu, dapatlah dikatakan bahwa pengadaan tanah yang dianut UU Nomor 2 Tahun 2012 adalah dalam pengertian agraria yang didalamnya terkandung tiga dimensi, yakni, dimensi tanah, dimensi terhadap segala yang ada di atas tanah, serta dimensi terhadap segala apa yang ada dan terkandunr di bawah tanah.

Dalam kaitannya dengan kepentingan umum, John Salindeho menjelaskan, bahwa istilah kepentingan umum dapat saja dikatakan untuk keperluan, kebutuhan dan kepentingan orang banyak atau tujuan sosial yang luas, atau dapat didefinisikan, bahwa kepentingan umum adalah termasuk kepentinganbangsa dan negara serta kepentingan bersama dari rakyat dengan memperhatikan segi-segi sosial, politikpsikologis dan Hamkamnas atas dasar asas-asas Pembangunan Nasional dengan mengindahkan Ketahanan Nasional serta Wawasan Nusantara.

Pengertian normatif dari istilh kepentingan umum termuat di dalam rumusan pasal 1 angka 6 UU Nomor2 Tahun 2012, dimaksud Kepentingan Umum adalah Kepentingan bangsa, Negara dan masyarakat yang harus diwujudkan oleh pemerintah dan digunakan sebesarbesarnya untuk kemakmuran rakyat.

Dengan merujukpada pengertian normatif di atas, maka penggunaan istilah kepentingan umum dalam kaitannya pengadaan tanah senantiasa terkait dengan penerapan prinsip kemanusiaan, keadilan, kemanfaatan, kepastian, keterbukaan, kesepakatan, keikutsertaan, kesejahteraan, keberlanjutan dan keselarasan sesuai dengan nilai-nilai berbangsa dan bernegara.

Sehubungan dengan hal tersebut, sehingga penggunaan istilah keppentingan umum disini tidak meniadakan kepentingan pribadi/badan ataupun perseorangan. Akan tetapi eksistensi dari kepentingan umum, derajatnya lebih tinggi dari pada kepentingan pribadi orang perseorangan ataupun badan hukum dan kelompok masyarakat tertentu. Namun harus difahami, bahwa di dalam pengertian kepentingan umum di dalamnya sudah terkandung kepentingan pribadi ataupun perseorangan.

2. EFEKTIVITAS

HUKUM

\section{PENGADAAN TANAH}

Pada prinsipnya, efektivitas pelaksanaan pengadaan tanah harus sesuai dengan asas hukum yang berlaku. 
Eksistensi asas hukum disini, hendaknya dipandang sebagai dasar fundamental pembentukan sesuatu aturan hukum. Hal ini dimaksudkan, agar aturan hukum yang dimuat sesuai dengan kebutuhan dan keinginan masyarakat.

Menurut pandangan Theo Huijberst bahwa suatu asas hukum merupakan prinsip yang dianggap dasar atau fundamen bagi hukum. Asas-asas hukum ini disebut juga pengertian-pengertian dan nilai-nilai yang menjadi titik tolak bagi kepentingan suatu perundangan dan/atau interprestasi peraturan perundang-undangan.

Sudikno Mertokusumo (1996 : 5) menyatakan : bahwa asas hukum sebagai pikiran dasar yang umum dan abstrak, atau merupakanlatar belakang peraturan konkret yang terdapat didalam dan di belakang setiap sestem hukum yang menjelma dalam peraturan perundang-undangan yang merupakan hukum positif dan dapat ditemukan dengan mencari sifat-sifat atau ciri-ciri yang umum dalam peraturan konkret. Lebih lanjut dikatakan, bahwa menurut ilmu hukum eksistensi asas hukum meruoakan jantungnya peraturan hukum.

Dengan demikian, maka asas hukum yang akan diuji efektif atau tidak efektif berlakunya dalam pelaksanaan pengadaan tanah bagi pembanguan untuk kepentingan umum, adalah asas hukum yang tersebar di dalam UU Nomor 2 tahun 2012, berikut berbagai peraturan perundang0undanagan yang menjadi regulasi/peraturan pelaksanaannya.

Indonesia sebagai negara hukum (pasal 1 ayat (3) UUD Tahun 1945), berarti mempunyai politik hukum pertanahan, Sedang politik hukum pertanahan Indonesia (UU Nomor 5 Tahun 1960) ditindaklanjuti dengan UU Nomor 2 tahun 2012, telah menetapkan asas-asas penyelenggaraan pengadaan tanah bagi pembangunan untuk kepentingan umum.Adapun asas-asas hukum pertanahan yang dimaksud disini yakni asas hukum sebagai sesuatu yang melahirkan peraturan-peraturan/aturan aturan hukum, merupakan ratio logis dan aturan ataupun peraturan hukum. Oleh karena itu setiap asas hukum selalu abstrak dari aturan ataupun peraturan hukum.

Sehubungan dengan hal tersebut, maka setiap pelaksanaan pengadaan tanah selalu diperhatikan daya mengikatnya asas hukum yang terkandung di dalam peraturan dasarnya, Apabila asas-asas hukum dilanggar, secara ex officio dapat mem-engaruhi keabsahan pengadaan tanah. Asas hukum pengadaan tanah bagi pembangunan untuk kepentingan umum, secara limitatif di atur dalam pasal 2 UU Tahun 2012. 
Adapun asas-asas hukum pelaksanaan pengadaan tanah bagi pembangunan untuk kepentingan umum, terdiri dari:

1. Asas kemanusiaan, bahwa setiap pengadaan tanah harus memberikan perlindunagn serta penghormatan terhadap hak asasi manuisa, harkat dan martabat setiap warga negara dan penduduk Indonesia secara proporsional.

2. Asas keadilan, bahwa memberikan jaminan penggantian yang layak kepada pihak yang berhak dalam prosesi pengadaan tanah melangsungkan kehidupan yang baik.

3. Asas kemanfaatan, bahwa hasil pengadaan tanah mampu memnerikan manfaat secara kuas bagi kepentingan masyarakat bangsa dan negara.

4. Asas kepastian, bahwa meberikan kepastian hukum tersedianya tanah dalam proses pengadaan tanah untuk pembanguan dan memberikan jaminan kepada pihak yang berhak untuk mendapatkan ganti kerugian yang layak.

5. Asas keterbukaan, bahwa pengadaan tanah untuk pembanguan dengan memberikan tanah untuk pembanguan dilaksanakan dengan memberikan akses kepada masyarakat untuk mendapatkan informasi yang dikaitkan dengan pemgadaan tanah.

6. Asas kesepkatan, bahwa proses pengadaan tanah dilakukan dengan musyawarah para pihak tanpa unsur paksaan untuk mendapatkan kesepakatan bersama

7. Asas keilutsertaan, bahwa dukungan dalam penyelenggaraan pengadaan tanah melalui partisipasi masyarakat, baik secara langsung maupun tidak langsung, sejak perencanaan sampai dengan kegiatan pembangunan.

8. Asas kesejahteraan, bahwa pengadaan tanah untuk pembangunan dapat memberikan nilai tambah bagi kelangsungan kehidupan pemilik dan masyarakat secara luas.

9. Asas kelanjutan, bahwa kegitan pembanguan dapat berlangsung terus menerus, berkesinambungan, untuk mencapai tujuan yang diharapkan.

10. Asas keselarasan, bahwa pengadaan tanah unruk pembangunan dapat seimbang dan sejalan dengan kepentingan masyarakat dan negara.

Pentingnya mematuhi dan mentaati asas -asas hukum dakam rangka pelaksanaan pengadaan tanah bagi pembangunan untuk kepentingan umum 
(Pasal 2 UU Nomor 2 Tahun 2012), diharapkan agar tujuan hukum dapat diwujudkan. Sedangkan tujuan hukum menurut Lawrence M. Frienmann ${ }^{4}$, yakni keadilan, kemanfaatan dan kepastian hukum. Tiga tujuan hukum dimaksud harus sesuai dengan sistem hukum Indonesia. Secara teoritis, sisten hukum kompnennya terdiri atas struktur, substansi, dan budaya hukum.

Sehubungan dengan hal tersebut, dalam membuat regulasi tentang pengadaan tanah para pejabat yang berwewenang telah berupaya semaksimal mungkin mamakukkan jiwa dan semangat yang terkandung dalam tujuan hukum untuk ditranfer ke dalam tujuan pengadaan tanah bagi pembangunan untuk kepentingan umum.

Kemampuan mengenai tujuan dilaksanakannya pengadaan tanah bagi pembanguan utuk kepentingan umum, diatur secara transfaran di dalam rumusan Pasal 3 UU Nomor 2 tahun 2012. Adapun tujuan pengadaan tanah dimaksud, untuk menyediakan tanah bagi pelaksanaan pembanguan guna meningkatkan kesejahteraan dan kemakmuran bangsa dan negara, dan masyarakat dengan tetap

\footnotetext{
${ }^{4}$ Ali, op.cit.,hlm. 5-7.
}

menjamin kepentingan hukum pihak yang berhak.

Pada prinsipnya mengenai pokokpokok penyekenggaraan pengadaan tanah bagi pembangunan untuk kepentingan umum di Indonesia, secara liminatif diatur dalam rumnusan Pasal 4,5,6,7,8 dan $9 \mathrm{UU}$ Nomor 2 tahun 2012. Adapun yang menjadi poko-pokok penyelenggaraan pengadaan tanah dimaksud, antara lain :

a. Pemerintahndan pemerintah daerah menjamin tersedianya tanah dan pendanaan untuk kepentingan umum`

b. Pihak yang berhak berkewajiban melepaskan tanahnya setelah memperoleh ganti kerugian, atau setelah ada putusan pengadilanyang berkeuatan hukum tetap.

c. Pemerintah yang menyelenggarakan pengadaan tanah bagi pebangunan untuk kepentingan umum

d. Pengadaan taah untuk pembanguan bagi kepentingan umum diselenggarakan sesuai dengan :

1. Rencana Tata Ruang Wilayah

2. Rencana Pembagunan Nasional/Daerah

3. Rencana strategis

4. Rencana kerja setiap instansi yang memerlikan tanah`

e. Pengadaaan tanah dilakukan untuk insfrastruktur minyak, gas dan panas bumi, pemgadaannya dilaksanakan 
berdsarkan Rencana Strategis dan Rencana Kerja Instansi yang memerlukan tanah.

f. Pengadaan tanah bagi pebangunan untuk kepentingan umum diselenggarakan melalui perencanaan dengan melibatkan semua pemangku kepentingan (pemuka adat, serta tokoh agama), dan pemegang kepentingan (orang atau pihak yang memiliki kepentingan terhadap obyek pelepasan tanah, seperti pihak yang berhak, pemerintah dan masyarakat)

g. Substansi hukum yang diatur dalam UU Nomor 22 Tahun 2012 wajib dipatuhi dan ditaati oleh :

1. Pihak yang berhak

2. Pihak yang menguasai obyek pengadaan tanah.

h. Penyelenggaraan tanah bagi pembangunanuntuk kepentingan pembangunan dan kepentingan masyarakat.

i. Pengadaan tanah bagi pembangunan untuk kepentingan umum dilaksanakan dengan memberikan ganti kerugian yang layak dan adil.

Berkenaan dengan pokok-pokok [emnyelenggaraan pengadaan tanah bagi pembangunan utnuk kepentingan umum tersebut, teramat penting untuk diketahui bahwa yang dimaksud dengan infrastruktur minyak, gas dan panas bumi, terutama yang mencakup kegiatan eksplorasi, transmisi dan/atau distribusi.

Selanjutnya, karekteristik dari kegiatan minyak, gas dan panas bumi mengandung ketidakpastian tinggi, sedang kebutuhan tanah untuk eksplorasi, transmisi dan/atau distribusi tidak dapat ditentukan secara papspti sejak awal sehingga membutuhkan fleksibilitas perencanaan untuk menjamin efektifitas pelaksanaan pengendalian minyak, gas dan panas bumi sebagai sumber daya alam serta sumber daya pembanguann yang bersifat strategis dan vital.

Hasil kajian tim berupa rekomendasi diterima atau ditolaknya keberatan rencana lokasi pembangunan dalam waktu paling lama 14 (empat belas) hari kerja terhitung sejak diterimanya permohonan oleh gubernur. Gubernur berdasarkan rekomendasi mengeluarkan surat diterima atau ditolaknya keberatan atas rencana lokasi pembangunan di tempat lain.Kemudian setelah penetapan lokasi pembanguan masih terdapat keberatan, pihal yang berhak terhadap penetapan lokasi dapat mengajukan gugatan ke pengadilan Tata Usaha Negara setempat paling lambat 30 (tiga puluh) hari kerja sejak dikeluarkannya penetapan lokasi.

Pengadilan Tata Usaha Negara memutuskan diterima atau ditolaknya 
gugatan dalam waktu paling lama 30 hari (tiga puluh) hari kerja sejak diterimanya gugatan. Pihak yang berkeberatab terhadap putusan pengadilan Tata Usaha Negara dalam waktu paling lama 14 (empat belas) hari kerja dapat mengajukan kasasi kepada Mahkamah Agung Republik Indonesia.

Mahkamah Agung wajib memberikan putusan dalam waktu paling lama 30 (tiga puluh) hari kerja sejak permohonan kasasi diterima. Putusan pengadilan yangbtelah mempunyai kekuatan hukum tetap menjadi dasar diteruskan atau tidaknya pengadaan tanah bagi pembangunan untuk kepentingan umum. Gubernur bersama instansi yanhg memerluikan tanah mengumumkan penetapan lokasi pembangunan untuk jepentingan umum dimaksudkan untukmpemberitahuan kepada masyarakat bahwa di lokasi tersebut dan dilaksanakanpembangunan untuk kepentingan umum.

\section{PENUTUP}

Politik hukum pertanahan di Indonesia termuat di dalam rumusan Pasal 2 dan Pasal 4 UUPA, bahwa negara bukan pemilik sehingga negara tidak memiliki tanah. Oleh karena itu, di dalam UUPA tidak dikenal istilah eigendom. Akan tetapi keberadaan negara dalam lingkup pertanahan, hanya diberi wewenang mengatur terhadap berbagai persoalan yang menyangkut pertanahan di Indonesia, termasuk wewenang pengaturan pertanahan yang semakin penting terutama apabila ada instansi pemerintahanyang membutuhkan tanah sebagai lahan tempat pelaksanaan pembangunan untuk kepentingan umum.

Tercapainya kepastian hukum dalam pemenuhan kebutuhan tanah terhadap instansi pemerintah bagi pembangunan untuk kepentingan umum, dipandang perlu adanya suatu aturan hukum yang dapat dijadikan acuan secara hukum positif. Dengandemikian, keberadaan Tim Lembaga Pertanahan dan/atau Panitia Pengadaan tanah dituntut untukmenyelenggarakan pengadaan tanah, sesuaiketentuan perundang-undangan yang berlaku.

\section{DAFTAR PUSTAKA}

Ali, Achmad. Mempelajari Kajian Empiris Terhadap Hukum. Jakarta :Watampone, 1998.

Sutedi, Adrian. Peralihan Hak atas tanah dan Pendaftarannya.Jakarta: Sinar Grafika, 2007.

Dwiyanto, Agus. Mewujudkan Good Governance Melalui Pelayanan Publik, (Editor). Yogyakarta: 
Gadjah Mada University Press.

Handoko, Widhi.Kebijakan

Hukum 2008 .

Pertanahan Sebuah Refleksi

Syafrudin, Ateng. Menuju Pemerintahan

Keadilan Hukum Progresif,

yang Bersih dan Bertanggung Yogyakarta: Thafa Media, 2014.

Jawab. Bandung: Jurnal Pro

Justitia, UniversitasParahyangan.

2002.

Sunggono, Bambang. Metodologi

Penelitian Hukum. Jakarta:

Rajawali Press, 2005.

Limbong, Bernhard. Pengadaan Tanah

Untuk Pembangunan, Jakarta:

Pustaka Margareta, 2015.

Widya Muliawan, Jarot .Cara

MudahPahami Pengadaan Tanah

Untuk Pembangunan, Jogyakarta:

Litera. 2016

Lubis , Mh. Yamin dan Abd. Rahim

Lubis,. Hukum Pendaftaran

Tanah. Bandung: Mandar Maju.

2010

Mahfud, M.D, Moh. Politik Hukum di Indonesia. Jakarta: Rajawali Press, 2009

H., H.S, Salim, dan Erlies Septiana Nurbati, Penerapan Teori Hukum pada Penelitian Disertasi dan Tesis. Jakarta: Rajawali Press. 2014.

Rahardjo, Satjipto . llmuHukum. Bandung: Alumni. 1986. 